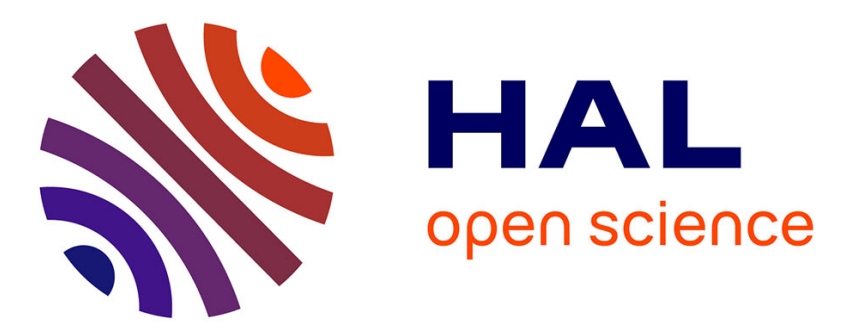

\title{
On prenatal diagnosis and the decision to continue or terminate a pregnancy in France: a clinical ethics study of unknown moral territories
}

Marie Gaille

\section{- To cite this version: \\ Marie Gaille. On prenatal diagnosis and the decision to continue or terminate a pregnancy in France: a clinical ethics study of unknown moral territories . Medicine, Health Care and Philosophy, 2016, 19(3), pp. 381-391. 10.1007/s11019-016-9689-2 . hal-01308978}

HAL Id: hal-01308978

https://hal.science/hal-01308978

Submitted on 29 Apr 2016

HAL is a multi-disciplinary open access archive for the deposit and dissemination of scientific research documents, whether they are published or not. The documents may come from teaching and research institutions in France or abroad, or from public or private research centers.
L'archive ouverte pluridisciplinaire HAL, est destinée au dépôt et à la diffusion de documents scientifiques de niveau recherche, publiés ou non, émanant des établissements d'enseignement et de recherche français ou étrangers, des laboratoires publics ou privés. 


\author{
UNKNOWN MORAL TERRITORY ${ }^{1}$ \\ ON PRENATAL DIAGNOSTICS AND THE DECISION \\ TO CONTINUE OR TERMINATE A PREGNANCY: \\ A CLINICAL ETHICS STUDY IN FRANCE
}

\title{
Introduction
}

Throughout the $20^{\text {th }}$ century, diagnostic techniques have been improved in industrialized countries, yielding greater knowledge about the health of the embryo, of the fetus, and of the mother. They have raised ethical, political, and legal issues that deserve our attention. Initially, research and treatment focused on perinatal care: the mother's health during and after pregnancy, and that of the infant in the first months of life. Research was then redirected to the embryo, for the purpose of diagnosing pathologies more accurately. This trend was due in part to the fact that the risk of contagious disease had largely been vanquished. In the 1940s, the work of A. Hertig, G. Pincus, and J. Rock also steered science in this direction. The description of the human karyotype dates from 1956. Cytogenetics and techniques for in vitro cell culture were developed and improved, alongside developments in ultrasonography. Once it was possible to diagnose in utero pathologies for which postnatal treatment is sometimes lacking, the parental couple and medical team caring for the woman during the pregnancy faced new questions: if the diagnosis of pathology is certain, should the pregnancy continue or be terminated? In the name of what, and in favor of whom could such a decision be made? These issues are still at stake today, even if non-invasive techniques have become available for prenatal diagnosis (Schmitz 2013).

Social sciences have studied how the use of these techniques has spread in various national contexts, their specificities and institutional organizations of prenatal diagnosis consult (Vassy 2011, 2014b). In addition, they have studied the social and professional acceptance of such techniques (Vassy 2005 et 2012). This article has a different purpose: to "closely examine the ways healthcare professionals and patients live with these technologies on a daily basis, and the impact of the technologies on their practices, expectations, and self-image, as either individuals or professionals" (Massé 2010).

This impact may be observed at different moments, for example when a diagnosis is revealed to patients (Legros 2005; Vassy and Champenois-Rousseau 2014). This article focuses on another moment: when the «patients» are led to reflect on the possibility to terminate or not the pregnancy after having been informed. It intends to highlight their reasons to make their decision in one way or another. We cannot presume that they are similar to the reasons we know of, in the cases of abortion without an indication for a medical reason (Bateman 1979-1980, 1982a and 1982b; Memmi 2003 ; Boltanski 2004).

\footnotetext{
${ }^{1}$ This title echoes Rayna Rapp's description of pregnant women confronting a prenatal diagnosis as "moral pioneers" (R. Rapp 2000), also referred to by C. Williams et al. (2005).
} 
Most of the studies that have been published on this topic concentrate on the point of view of medical teams (Williams 1982 and 2002 ; Geller 2002 ; Dommergues 2010). The present article intends to contribute to a better understanding of the patients' point of view (McCoyd 2009; Mirless 2000 and 2011). More specifically, it deals with the patients' point of view when the diagnosis reveals a genetic disease and raises the issue of hereditary illnesses (Dekeuwer and Bateman 2011 et 2013). Here, the term "patient" describes either the pregnant woman alone, or the parental couple. These people are the medical team's "patients" in the literal sense of the word, for they are interlocutors in a healthcare situation. They are also their "patients" in a more metaphorical understanding: because they are facing a painful ordeal, they are treated with special attention by the healthcare team.

Here, I aim at presenting the reasons formulated by the patients in order to ground their decisions to terminate or not the pregnancy. The focus of my study is not the rhetoric of justification (Boltanski, 1990, Boltanski et Thévenot, 1991) which has been already examined in the case of abortion without medical indication (Memmi, 2003 ; Boltanski, 2004). I rather intend to highlight the way the patients deliberate, the rythm and course of their reflection, their doubts and concerns, the influence of their personal and family history on their decisions.

In order to do so, I would like to present a part of the results of a clinical ethics study that I have supervised for the Clinical Ethics Center based in Cochin Hospital (Paris, France) between 2011 and 2014. This study investigated the reasons put forth by patients who confronted the question of terminating a pregnancy after they were informed about a prenatal diagnosis. The first part of this article will reveal the legal and social context of the study, its goal and methodology, how it proceeded, and the pathological situations encountered. Its second part will present and analyze the reasons formulated by women and parental couples facing the decision to continue or terminate a pregnancy. Finally, the article will examine the patients' complex relationship to the medical decision at stake. The analysis of the interviews enables to perceive the ordeal they experience and the way they confront the suspicion of "eugenics choice".

\section{Study presentation}

The legal and social context

To understand the point of the study, it is necessary to specify the French legal framework for medical termination of pregnancy. The right to choose to terminate a pregnancy is legal since 1975 and the cost of the procedure is covered by national health insurance. It is allowed without any indication of a medical reason up to 12 weeks of pregnancy since 2001. After these 12 weeks, an indication of a medical reason becomes necessary. In such cases, an abortion can be performed "at any time [in the pregnancy] if there is a strong probability that the child to be born has an especially serious condition, recognized as incurable at the time of diagnosis" (art. L. 2113-1of the French Public Health Code, Code de la Santé Publique, CSP). In 2001, the CSP adopted the term “voluntary termination of pregnancy for medical reasons" (art. R. 2213-1). When a pregnant woman wishes to terminate her pregnancy on the basis of a medical reason, she must send her request to a Centre Pluridisciplinaire de Diagnostic Prénatal (Multidisciplinary Prenatal Diagnostics Center). It will decide whether or not to accept it. If the woman or the parental couple's request to terminate the pregnancy is validated, they are granted with a week of reflection to confirm their wish. This type of center, subject to licensing by the Agence de la 
Biomédecine every five years, was created to ensure follow-up on prenatal screening procedures (art. L. 2231-1, CSP). Their role is to inform patients about the diagnosis or prognosis of the condition, and to provide counseling services. The very concept of prenatal diagnosis is defined by the law as all of the "medical practices carried out for the purpose of detecting in utero in the embryo or fetus any especially severe condition" (art. L. 223-1, CSP).

Therefore, there is no question as to the legal possibility of terminating the pregnancy as long as the medical indication meets the criteria for incurability or special severity indicated by the law. Because the costs of the procedure are covered by universal health insurance, any economic barrier to terminating the pregnancy is eliminated. The questions that arise are related to other issues: for the pregnant woman or parental couple, that of the continuation or termination of the pregnancy, as a function of what prenatal screening makes it possible to learn about the future life of the unborn child; for the medical team, the diagnosis of an especially serious disease or disorder, incurable at the time of diagnosis, and the position the team will adopt in relation to any request that may be forthcoming from the pregnant woman or the parental couple, regarding continuing or terminating the pregnancy; for the society at large, that of the organization of the health care system and its policy information regarding prenatal diagnosis.

\section{Objective}

The study presented here focuses on the deliberation process and the course of the patients' reflection after a prenatal diagnosis was revealed to them. It deals with the way they convince themselves about the relevance of such and such reason to terminate or not the pregnancy. The interviews with the patients were made after the consult in which they were informed about the diagnosis, and before they made their decision about continuing or terminating the pregnancy. They were presented to the patients as a specific moment of ethical conversation (Parker, 2012), aside from the medical consults.

The study presented here was driven above all by the question of meaning, "the meaning an agent actually subjectively intends, on a particular historical occasion" (Weber 1956). It sought to understand this meaning as it was stated in the process of making the decision and not in retrospect. As a matter of fact, in the time following the decision, individual memory and reflection intervene (Schütz 2010) and are likely to color or change the reasoning given for the decision. Finally, the purpose of the interviews was not only to amass factual information. It was also to acquire a genuine grasp of the feelings, values, beliefs, convictions, and interpretations making up the heart of the experience confronted by patients, the medical team and, in some cases, patient proxies.

Methodology

The study is based on the clinical ethics research methodology as it has been elaborated by the Clinical Ethics center based in Cochin Hospital. It was chosen because it allows to gather factual information and to elaborate a qualitative approach of medical decisions and their ethical dimension. As a matter of fact, it maintains some kinship to medical anthropology as theorized by A. Kleinman. Both pay attention to the way in which the agents 
in the medical situation, caregivers, patients, and families, experience and formulate the ethical issues in healthcare situations (Geertz 1973; Kleinman 1988 and 1997; Parker, 2012).

This study was carried out between 2011 and 2014 in a prenatal screening center in Paris. It involved a team of 5 interviewers trained in clinical ethics, coming from a variety of professional and academic horizons (psychology, philosophy, law, medicine, civil service/social affairs administration). It proceeded by semi-directive interviews (lasting between 45 minutes and two hours, depending on the interviewee). They were made by a team of two persons trained in clinical ethics, one of whom is a practicing medical professional and one of whom is not, in order to obtain two different perspectives on the case. It constituted a series of case studies related to the same decision. Without seeking exhaustive knowledge, the study intended to base its findings on a sample size beyond which the addition of more cases would not add anything to the knowledge already acquired (Glaser and Strauss 1967). It required constant attention to the feelings of the patients who agreed to be interviewed. We were careful not to offend them with the questions we asked, at a time when they were going through a painful ordeal.

The study unfolded in three phases. First, a protocol was drafted in collaboration with the medical team at this center (over 9 months). The protocol established that a member of the medical team, designated as the "referring person," would explain the clinical ethics study to the patient (the pregnant woman or parental couple). Once a patient had given preliminary consent to participate, this referring person put us in touch with the woman or couple.

During 18 months, a series of 28 interviews were carried out with patients (involving 5 women consulting the center alone and 23 couples). We recorded some standard information: age, situation, family history; gestational age, pregnancy profile and history, family history of disability or disease; the circumstances of the prenatal screening, and the effects associated with the diagnosis. We sought to understand the patients' conceptualization of disability and disease. We also explored their knowledge of the law and their opinion of it. We tried to grasp the importance of other people's opinion to them: their family, friends, colleagues at work, and society as a whole. They explained to us what they saw as the chief motivations for their decision to continue or terminate the pregnancy and the "ethical" dimension of this decision.

We combined these interviews with 7 interviews carried out with members of the medical team (one nurse, two midwives, a geneticist, a psychologist, and two obstetrician-gynecologists, one of whom is also a sonograph technician). We sought to understand their respective career paths and the way they conceive of their profession, in relation to the ethical issues raised by the decision to terminate a pregnancy for medical reasons. Because it was not the purpose of the study, we did not sift the findings of these interviews with the aim of determining whether certain opinions matched up to certain professions within the prenatal screening team (Parker, 2012). Instead, we chose to identify the ethical, professional, and scientific commitment each associates with her work, in order to shed light on the nature of the patient/doctor relationship established by the Prenatal Diagnostics Center. We examined the overall context in which decisions are made, and the various agents' reasons to agree or not wit the patient's point of view. ${ }^{2}$

After the interview phase, the next step was thematic analysis of the interview data. It intended to identify the reasons to terminate or not the pregnancy, the terms in which the meaning is expressed, and the ethical dimension associated with it (9 months).

\footnotetext{
${ }^{2}$ This other part of the study will be presented in another text.
} 
Pathologies of the encountered clinical situations

The pathologies revealed by the prenatal screening were of very different types. Nine couples confronted the diagnosis of a deadly pathology. For the other 19, the pathology was not life-threatening.

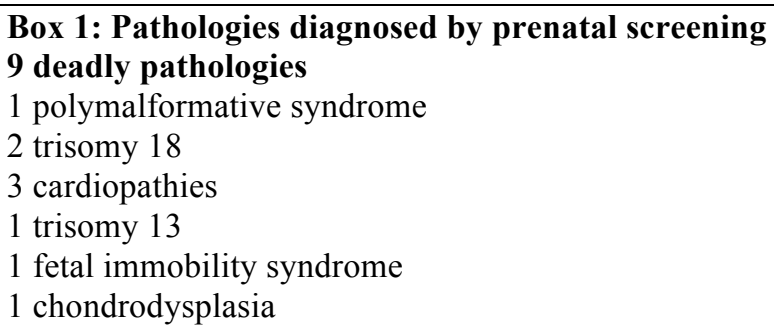

The following pathologies were perceived as serious by patients without certainty:

2 spina bifida

2 ageneses of the corpus callosum

1 Peutz-Jeghers syndrome

1 facioscapulohumeral muscular dystrophy

\section{The reasons to terminate or not the pregnancy}

To get familiar with the reasons for which women and parental couples decide to continue or terminate a pregnancy in France is a delicate task. First of all, in this country as elsewhere (Asch 1999), one reason is frequently mentioned as a good-enough explanation of the choice to terminate a pregnancy: that of an unfavorable social context to disability. In addition, this issue is too often covered by the media and discussed by bioethicists in ways that are furious or fiercely advocatory, especially in relation to cloning and the "Brave New World" utopia. Some researchers in social sciences, politicians, health professionals, church spokesmen condemn eugenics choices supposedly made by future parents and medical teams (Vassy et ChampenoisRousseau 2012; Gaille and Viot, 2013). As this study shows, things are more complex and need a thorough examination before any moral judgment may be elaborated on the decision to terminate or not a pregnancy made on the basis of a medical indication.

In the vast majority of the cases examined ( 24 of 28 ), the decision was made to terminate the pregnancy. Of the four decisions to continue the pregnancy, two involved fatal pathologies and two non-fatal pathologies. As we observe, the fatal character of the pathology does not ground the decision to terminate the pregnancy, the nonfatal character of the pathology does not justify the decision to continue the pregnancy. 
Two main reasons were elaborated by patients: personal and family stability, and the quality of life for the child to be born. They are not unheard of in French context (Dusart et Thouvenin, 1995). However, they have been identified mainly in studies on health professionnals' point of view. In addition, as formulated by patients, they concentrate much more questions and worries than the ideas of a "life of suffering for the child" or that of "an unbearable burden for the family" may convey. The reason associated with the quality of life of the child to be born refers to the organic as well as to the psychic dimension of the person. It also includes the lack or insufficiency of social life and the perspective of a «medicalized» life. Finally, it relates to the issue of caring for a sick or disabled person when her parents are deceased. As far as the personal and family stability is concerned, the problem is not the « burden » to raise a sick or disabled person. It rather lies in the capacity of her parents, brothers and sisters and family at large to welcome her and to go on in their own lives. This reason focuses on the psychic capacities of the family members. It is implicity grounded on a conception of the individual envisioned not as a separate being but in the web of social and affective relationships. Other reasons were formulated. But they were conceived as non-decisive : the social and economic context in which the child to be born would be raised; the spiritual or religious dimension of the reflection. The interviews revealed the process of hierarchization that took place in it in order to distinguish between actual reasons to terminate or not the pregnancy and what we may call « contextual» elements of the decision.

Two preponderant reasons for action: personal and family stability, and the quality of life for the child to be born

First of all, in most of the interviews, a cluster of expressions, questions, and concerns formed around the idea of personal and family stability. It constituted the primary and principal reason. It is formulated with regard to oneself, to the couple and to the family with children who are already born. Often, it is accompanied by anxious self-examination about one's ability, as an individual, couple, or family, to cope with disease, disability, and the prospect of a short life expectancy. This reason was especially striking in the two cases where the pregnancy had been achieved through assisted reproduction techniques. In these situations, couples say they cannot bear the idea of a child who is disabled or ill, after all of the difficult reproductive procedures they have had to undergo. "I've suffered enough to do without having anyone preach to me about my duty," explained Valeria. "Raising a child involves your heart and your mind. You rely on your dreams. In this case, it's impossible. No one dreams of having a child like ours."

Beyond these two cases, it appears in most of the interviews. For example, Yasmina attended the interview alone, and was confronted with the decision to undergo a second medical termination of pregnancy. She expressed her search for stability in reference to three factors in her personal and family life: her husband "who can't do anything without [her]," the needs of her first child, and lastly, her own career (she had gone back to school, and considered that keeping the child would endanger her ability to study and work).

In some cases, this reason was expressed with absolute certainty. Marc and Marianne spoke of a "cross to bear," of "self-sacrifice": they mentioned friends who had divorced, "driven mad" after they had had a disabled child. In their eyes, a disabled person "disrupts everything, family, lifestyle choices, where to live". In other cases, the decision was the final step in a thought process that acknowledged doubt and hesitation. For example, Marielle and Jean, aged 33 and 34, already have a two-and-a-half-year-old child. The second pregnancy was already underway when they were informed about the pathological condition of their first child. For the second 
pregnancy, a sonography performed at 18 weeks of gestational age, was recommended as a "formality". It showed the fetus had a cardiac malformation: agenesis of the pulmonary valves - a defect operable with a success rate of $70-80 \%$. As soon as they were informed about this condition, they began wondering about their capacity to deal with open-heart surgery. They disagreed: he was in favor of MTP, while she opposed it, somewhat. However, they described themselves as going through the painful ordeal together, sharing the same types of questions. Jean indicated he had a "history" (meaning a history of mental illness): he attempted suicide at the age of 23 , and his brother had died four years ago. Marielle described herself as a psychologically fragile person. Neither of them could see themselves "making a radical life change," because they were fulfilled by their employment and the time they spend with their first child. They also said their goals were to preserve their "home" and couple. However, before we met them, Marielle and Jean had decided to "take the time" to think "to the best of [their] abilities," and to discuss the matter with other physicians, parent groups, and Catholic priests. They also saw their participation in the clinical ethics interview as a way of clarifying their ideas to themselves.

The second cluster of expressions, questions, and concerns formed around the idea of the quality of life possible for the unborn child, throughout his or her lifetime. It often paired with the first reason. It involved various questions: will the child suffer? Will her/his life be highly "medicalized?" Will she/he be able to speak, walk, eat, lead an "autonomous" life, love a partner, and have children? Will she/he be able to work? Won't she/he be stigmatized by intolerant social views? For example, when Tang learned that the child his wife was carrying had trisomy 21 , he wished to have the pregnancy terminated. He imagined the child would be unhappy as an adult: unable to marry, the butt of everyone's mockery.

When this reason is put forward, it is often formulated as an inability to accept the fact that one is giving birth to "a life of suffering." In the name of love and moral responsibility, continuing the pregnancy is described as a harmful or egotistical decision. "Out of love for our child, we are stopping," Arielle and Louis told us. Their primary motivation was to "avoid a life of suffering for the little thing." They attributed this suffering to the concept of "severe mental retardation" and an inability to breathe (a small nose), the result of a rare and complex pathology.

The belief that the human condition is difficult for everyone, both the fit and unfit, emerged from several interviews. This conviction was mobilized to support terminating the pregnancy. Mathieu, Caroline's partner, found out that the child the couple was expecting presented an anomaly of the sex chromosomes. The possible consequences of this anomaly for the child were testicular cancer, sterility, and anatomical malformations. Even though the life of the baby was not in danger, Mathieu believed it was his "duty as a father" to "ensure that the child has luck on his side," because "life on this planet is difficult." And the destructiveness of human beings is going to make it even worse. Mathieu said he wants to provide his children with "the maximum." As a result, he was critical of the way society stigmatizes disability but considered legitimate to devote more resources to the births of healthy children. Maria, an undocumented foreigner working as a domestic, was in France for 11 years. She told us that in her opinion, it was strange to want to keep a child with a disability in such a complicated world. Her reasoning mingled the life prospects of the child she was carrying and her own: "Life is already hard enough, so it's difficult to have a child with a disability, too."

In certain cases, personal experience with disability bolsters the conviction that disability has a negative impact on life quality. This experience is usually cited to justify a decision to terminate the pregnancy. The future of the 
child in gestation is presented as being too painful to continue the pregnancy in reference to an overly negative personal, familial or professional experience of disease or disability. The child Brunehilde and Emmanuel were expecting presented a relatively mild type of muscular dystrophy, inherited from Emmanuel. From the outset, the parents firmly asserted their intention to put an end to the chain of transmission of the disease. In their eyes, to do so was an "act of bravura," motivated by the wish to avoid giving birth to a child who would experience the same "frustration" as Emmanuel when he learned of his "difference."

Significant contextual elements but non-decisive reasons

Other reasons were put forward in the interviews, but they were not formulated as decisive ones, even though in certain cases, they might be considered to play an indirect role in the decision. As a matter of fact, they contributed to the parents' concern for the future child's quality of life. First of all, societal intolerance for disability in France was a factor. The patient sometimes mentioned the lack of infrastructure for caring for persons with disabilities and/or serious diseases at various ages (in a quarter of the interviews). When intolerance for people with disabilities was cited, evaluations of the situation in France diverged significantly. Serena, expecting a child with trisomy 21 , decided to continue her pregnancy. She was one of the only ones to express sharp criticism of the situation in France, comparing terminating the pregnancy to euthanasia. She pointed out contrasts between attitudes in France and the ones in her home culture, Catholic Brazil, pro-life in every form. "Is there anyone on Earth who is normal?" she asked. She criticized French society for "wanting perfect people." Malika's viewpoint was different. She wished to terminate her pregnancy (the fetus had been diagnosed with dwarfism). Nevertheless, in her opinion, persons with disabilities are treated much better in France than in the other two countries she is familiar with - Algeria, where she was born, and Egypt, her husband's homeland. There, she said, society does nothing for people with disabilities. The parents of disabled children are viewed at best with compassion and at worst with suspicion: "It's true, there, we'd have gotten either pity or questions: 'What on earth did that mother do wrong, to end up with a child like that?' And you can't build normal relationships on pity." Malika was one of the only respondents who broached the subject of social eugenics, saying screening practices raised ethical issues for her: "If they keep this up, pretty soon we'll have the kind of society Hitler wanted."

A second significant contextual element of the patients' reflection is the religious or spiritual dimension. Religious beliefs, spirituality, religious background, and all other forms of relationships to the "religious" were also mentioned by the "patients" in half of the interviews, with or without prompting. Often, it was shared with other family members. For example, when Yasmina, a Muslim, spoke of her faith, she said that she and her husband had been "a little concerned" in relation to their religion. They had discussed the matter with "scholars of religion." The latter tended to approve of the medical termination of pregnancy. "He [the imam] told us, 'If you know raising a handicapped child will be unbearable for you, you have no religious obligation to do it." Yasmina went on to say that even if the imam had disapproved of medical termination of pregnancy, she would not have changed her mind. Yasmina did mention that her religious belief had comforted her in her difficult circumstances: "everything, both good and bad, comes from God, who is bound to send [me] a normal child in the end." 
When we met with couples, they had not always agreed beforehand to a shared, established interpretation of the religious message. Min, a Buddhist, perceived medical termination of pregnancy as a murder that would create "bad karma" for the family, because the natural flow of things had been stopped. Her husband Tang disagreed, seeing this vision of religion as too monetized. He said that only the spirit mattered. He added: "you let go of the body."

In few cases, facing the decision to continue or terminate the pregnancy prompted a crisis in regard to the nominal religion, or at least a detachment from it. Maria stated that she is a Catholic, but immediately adds that she "doesn't care," and that she disagreed with the official Church position on abortion. Valeria emphasized the idea that her decision had severed her from her religion: "Until yesterday, I was a practicing Catholic; now, I am taking a break."

"Religion" or "spirituality" was considered as a significant but a non-decisive reason to the patients who referred to it. It contributed to give shape to their reflections, and often served as a moral compass in both types of decisions - to continue and to terminate the pregnancy. However, religion, as a culture, text, or institution, appeared very open to interpretation, and its normative power over the situation quite limited, in a way similar to that observed by sociologist Séverine Mathieu in assisted reproduction clinical cases and to that analysed by Habermas on more general grounds (Habermas 2006; Mathieu 2013).

\section{The dizzying heights where decision is taken}

In addition to letting us know about the reasons to terminate or not a pregnancy in patients' mind, the interviews gave a privileged access to a deliberative and complex process focused on a decision to be made. They let us understand the ordeal they experience. In addition, they offered us some elements to explain why the issue of "who decides?" is a key issue in France: even though french society may be described as individualistic up to a certain extent, the law grants the medical team with the responsibility to decide to continue or terminate the pregnancy. Patients were generally extremely surprised when they get to know of the content of the law. They claimed to be the only legitimate decision-makers. As a result, in the interviews, they elaborated a reflection very different from the one we may know of in other contexts, in which their part in the decision-making is undisputed and in which they may prefer, reversely, to devolve their right to decide to the medical team (Rapp, 2000). Finally, in these interviews, their deliberation also reveals itself as being partially determined by a social context in which the suspicion against « eugenics choices » is strongly expressed.

"I am the one to decide": a unanimous and often gendered claim

The interviews revealed both widespread ignorance of the law, and a unanimous demand: that "patients" be the sole authorities in deciding whether to continue or terminate the pregnancy. When the "patients" were informed of the actual text of the law, often in the course of the interview itself, or few days before during the consult with the medical team, they expressed great surprise. In their opinion, "it goes without saying" that the mother or parental couple should have the final word in the decision. In some cases, patients sought advice from someone they knew: some of them cited family and friends, while others suggested religious counselors. But these 
discussions only rarely had an impact on the decision. In every situation, "being judged by society" was rejected as irrelevant to the decision. Lastly, although the patients considered that it was the role of the medical team to provide information and counseling. They did not believe that the team should be entitled to any say in the final decision - contrary to the provisions of the law. "It is our business, and no one else should be able to choose for us", Vanessa and Julien asserted. As for Marianne and Marc, they intended to decide for themselves "because [we] were responsible" and because they, and no one else, would live with the consequences of their decision.

Therefore, whatever they decide, the "patients" want to take responsibility for the consequences of their decision. To account for this position, it is not enough to refer to an overall analysis of the evolution of the patient/doctor relationship in France since the 1980s, culminating in the passage of the law on patients' rights in 2002. The most significant point here seems to be that persons confronted with a decision to continue or terminate a pregnancy consider themselves as "responsible" for the child who will be born to such a degree that they sometimes renounce the birth. In their opinion, the legal framework should reflect this position of responsibility, above all. As a result, from an ethical point of view, they feel that they are on shaky ground in relation to the law.

In addition, in many cases the couples granted the woman the leading role in making the decision, although they did express a concern for consensus and shared decision-making. The partners might not reach agreement at the same time, but harmony was seen as desirable. Claudine and Claude, for example, took pride in finally having made the decision as a couple. They looked for "the right decision" together. In another configuration, Yasmina presented herself as the woman who had made the decision, albeit with the approval of her husband and the imam. Similarly, according to Mathieu, the weight of the decision is not equally distributed within the couple. He deliberately refrained from saying anything during an appointment with the medical team, feeling that Caroline had to be the one to decide.

Several factors explain why, in most situations, there was a feeling that the woman's decision should take precedence. The first and most obvious is that the woman is the one who is physically implicated in the pregnancy. The living presence of the unborn child is a constant reality to her. She is the one who will bear the brunt of the consequences of the decision, even socially: she was pregnant, and now she isn't. What happened? What did she do? Why? This factor seemed to carry more weight in situations where the pregnancy was already past the first trimester, and the woman could feel the fetus's movements. But it was not confined to them.

Nevertheless, it is important to point out that this primacy was not unanimously conferred on the woman by our couples: two made decisions to continue a pregnancy, overriding the woman's desire to terminate it. Fleur was afflicted with a syndrome she was opposed to passing on, like Emmanuel and Brunehilde, in the name of the moral responsibility not to transmit a disease when it has been diagnosed prior to birth. She began the interview by citing all the reasons she had for terminating the pregnancy. She told us she was familiar with "the hospital world," and that being perceived as a person with a disease had always been a source of suffering for her. Since childhood, she was monitored closely. To avoid any risk of passing on the disease, she initially did not wish to have a child. Married, she would have preferred to adopt. She finally agreed to undertake a pregnancy because her husband was opposed to adopting a child. When, as a pregnant mother, she learned the results of the choriocentesis, she told us she "collapsed." She appeared to be torn: her wishes conflicted with those of her husband and both of their families. Should she obey her own desires, and terminate the pregnancy, or "sacrifice 
herself" for her husband and the families? As "very religious Catholics," they would not be able to understand her decision. Because of these elements, she finally made her way to the decision to continue the pregnancy.

Grief caused by the decision

The process of decision was perceived as a terrible ordeal. The will to take responsibility for the decision does not eliminate doubt, guilt, shame, and anxiety about the present and future and rather go together with them: "Yes, it is ethical... it is painful," Claudine told us, without specifying what she meant by the term "ethical." Our respondents said or showed that engagement in ethical deliberation confronted them with a fundamental difficulty: ambivalence about a decision that might have been different, except for the small number of cases that appeared to be devoid of "uncertainty." Arnaud described being caught "between a rock and a hard place". He expressed the feeling of being forced to choose between two solutions, neither of which is desirable. What makes this time particularly painful for people facing the decision to continue or terminate a pregnancy is the prospect that a different decision could be considered. There are pros and cons to both sides. Moreover, in the future, they cannot count on anything that will justify or condemn their choice. For example, Arielle and Louis, who decided to terminate Arielle's pregnancy, made this comment about their decision: "For the love of our child, we are stopping. But we could just as easily say that for the love of our child, I cannot do that to him; take away his life. It is a strong argument either way." The possibility that the diagnosis might be mistaken, the fact that any diagnosis of the fetus's health and the future of the child is uncertain, increased the difficulty of making a decision for some. But this was not always the case: in some situations, the uncertainty was perceived as a disqualifying factor. It led directly to a decision to terminate the pregnancy.

Moreover, the interviews do not confirm the idea that the decision to interrupt the pregnancy implies emotional "disinvestment in the baby." (C. Allamel-Raffin 2008; Boltanski 2004). One third of the interviews described the decision made - to interrupt the pregnancy - as a decision to "kill the baby", incuding in some situations of first term pregnancy. For those who use this expression, the decision is not lightly taken, even if the law permits medical termination of pregnancy. Very often, the couple or the pregnant mother speak of their "baby," not of a "fetus," and plan to "say goodbye" to him. They think about a burial, birth and death registration, a first name. Sometimes, they even consider holding the baby in their arms. Some women found the words to express the inner conflict that was so difficult for them to bear. Caroline remarked, "My heart tells me it's my baby, and my mind says will I know how to care for this child?". Marielle, one of the respondents who described the decision to interrupt her pregnancy as a decision to "kill" the child, further described the alternative as "counter-intuitive" and "inhumane," especially for a mother. She could understand her husband's wish to interrupt the pregnancy for the sake of their marriage and the child they already had, but insisted on the irrepressible "animal" instincts leading her in the opposite direction.

Therefore, the interviews revealed that the decision is frequently experienced as an ordeal due to its very nature, and because it gives rise to painfully ambivalent feelings. At such times, in speaking to the other, one tries to convince both oneself and one's interlocutor that one has chosen the lesser of the two evils, once and for all. Our interviews often served as opportunities to review the reasons for the decision. As a result, the interviews demonstrate the very dynamic of the decision, the person's hesitations, the breakthrough factors for ethical reflection, and the nagging persistence of doubt and self-examination. 
The decision to terminate or not the pregnancy and "eugenics choices"

The difficuly character of the decision is barely related to the nature of the disease or of the disability by the patients. Considering the series of situations examined in the study, this may be explained first by the fact that, out of 28 cases, 9 were related to fatal pathologies. In these cases, patients did not reflect on the nature of the disability or the seriousness of the disease. The question they raised was that of the meaning for them of a decision to continue the pregnancy once they knew their child to be born would die few hours, days or weeks after the delivery.

In the situations of non-fatal pathologies, the interviews abounded with every possible form of rejection or acceptance of physical and mental disability, and their ranking. No general trend emerged from them. The word "disability" ["handicap," in French] was not invariably applied by the patients. Some spoke more readily of "disease," of "difference," of an opposition between "normal" and "abnormal." These variations in terminology hint that although each individual has constructed his or her own image of disability, usually limited to the representation of a trisomic person, the patients had not elaborated to any great degree the issue of disability, difference, or "abnormality." Sometimes, the interview itself was an opportunity to think about the matter. In one third of these situations involving a non-fatal pathology, the type of disability or pathology was at least partial grounds for the decision. For example, Caroline and Mathieu believe that dwarfism and sterility are not "harmless" disabilities. For Marie, the issue of "abnormality" was relevant in both practical and symbolic terms, and above all for the "parents," who must "accept the responsibility for a child who is not normal." She herself said she could cope with a cardiac malformation, but not with a cleft palate or clubfoot. Elodie, who had been notified of a diagnosis of trisomy 21 , said she could not imagine herself as the mother "of a handicapped child." She said she was grateful that science had progressed enough to make this knowledge available to the parents so they can "choose."

It turns out that the interviews rarely gave rise to discussion about the genetic aspects of the pathology that had been identified, even when the question of eugenics was explicitly asked. It was not always possible to introduce the question. When it was the case, it usually elicited expressions of indifference, like "this doesn't count," even when the intention to avoid transmitting the disease was present. When patients themselves broached the subject of eugenics, they defined the term vaguely, inappropriately, or not at all. In rare cases, eugenics was associated with a "punishment," with something shameful that should be concealed. Several "patients" associated eugenics with medical progress, making it possible to eliminate "bad genes," and to envisage a future free of disease. Others interpreted eugenics as something that engenders specific moral duties for the parents to refrain from transmitting a disease that could be identified in time, before birth. The word almost never indicated a moral and political problem from the patients' point of view. When it was the case, as in Malika's words quoted above, it was considered as less important issue than that of assuming the consequences of the decision in one's daily life. This perspective cannot be simply explained with the assumption that these patients are in denial of the social consequences of their own choices, or that they refuse any association whatseover with "eugenics" due to the negative moral charge carried by the term. First of all, they claim to be the only legitimate decision-makers. They are not worried about the supposedly perverse effect of the moral and political value of "autonomy" that appear in other national contexts as a screen of smoke used by governments to control life and fetus' quality 
(Schwennesen, 2010). In addition, as we have seen, they give their preference to reasons based on the consideration of their personal, couple and family life and of the (imagined) quality of life of the child to be born. In doing so, they partly agree with the French law that does not relate the decision to terminate a pregnancy to an established list of pathologies that would ground it in every case. To them, the general idea according to which it is morally legitimate to terminate a pregnancy because of such and such disease or deficiency, and especially cognitive ones (Singer, 1985 et 2002) is meaningless. The case by case approach set by the law fits their expectations. However, they also disagree with this law because it does not let them be the decisionmakers. This is the crucial issue raised by prenatal diagnosis to them, much more than the possible eugenics character of the decision to be made.

\section{Conclusion}

Two questions may be derived from the analysis presented in this article, that deserve further inquiry, including a wider approach in statistical terms. The first question is related to the great similarity between the reasons formulated to continue or to terminate the pregnancy, regardless of the pathology identified thanks to prenatal diagnosis. This result of the study - the wide use of the same two reasons for whatever purpose - is even more striking when we consider that interviewed patients covered a cross-section of the population that is heterogeneous in all three of the following respects: age; family, economic, social, and civil status; and background of the pregnancy. Ages ranged from 21 to 42 for the women and from 23 to 53 for the men. They came from a broad variety of occupational categories. Some were French citizens; some were not; some resided on French territory and some did not; some possessed the proper French identification documents and some did not. The background of the pregnancies also differed. Some of the women or couples already had children when we met them; others did not. Some of them were confronting the decision alone; others had to deal with their families. About $50 \%$ of them professed religious convictions (Islam, Catholic or Protestant Christianity, Judaism, or Buddhism). Those who declared a religion told us they expressed it in a variety of different ways: as a belief, a practice, a spiritual quest, or in counseling with a person from a religious background.

The second question lies in the issue of "eugenics choices". It is striking to observe that the reasoning of the patients we interviewed was more or less diametrically opposed to the terms prevailing in the seemingly “endless" debate on eugenics in France (Roussel 1996; Le Dref 2013) ${ }^{3}$. Indeed, they raise a delicate issue to be considered by French society: should the rejection of eugenics choices be an absolute ethical and legal principle? Or should this society grant moral legitimacy to the decisions to terminate a pregnancy (that amount to few thousands per year), and stop stigmatizing the patients and the medical teams with the suspicion of eugenics? In other words, which place is to be given, in moral reasoning, to the individual freedom to decide what is good for

\footnotetext{
${ }^{3}$ In France, this debate makes little or no reference to the idea of "geneticization," defined as a societal or cultural tendency to reduce individuals to their DNA (Lippman 1992), the sociological reality of which remains to be proved (Hedgecoe 2009). Nor is it related to human enhancement or to the quest for genetic perfection, in contrast to other contexts where this issue is more often discussed (Rose 2007; Savulescu and Bostrom, 2009; Bateman and Gayon 2015). This question is not entirely absent from the ethical discussion (Gayon and Jacobi 2006). However, the crux of the debate concerns determining the threshold for a life worth living, based on the hypothesis that certain types of life perceived as "defective" would be eliminated and the moral legitimacy of such a threshold (Gavarini 1990; Gaille 2010; Gaille et Viot, 2012; Vassy 2011 et 2014b).
} 
oneself, one's couple and one's family? Which moral status is to be granted to women and parental couples' capacity to tell what they feel responsible for and to assess the consequences of a birth on their lives over the long term?

\section{Compliance with Ethical Standards and Informed Consent}

The study protocol was validated by the CERES (Le conseil d'évaluation éthique pour les recherches en santé, Université Paris Descartes).

Informed consent was obtained from all individual participants included in the study.

The confidentiality of their statements was guaranteed to them.

\section{Acknowledgements and Funding information}

I want to express my warm thanks to the clinical ethics team with whom the study was carried out and who trusted me enough to let me propose the present analysis: Elisabeth Belghiti, Bernadette Broussille, Laurence Brunet, Véronique Fournier, and Géraldine Viot.

In the name of this team, I would also like to express my gratitude to the staff of the Centre de Diagnostic Prénatal who hosted us and, despite a heavy schedule, gave us some of its valuable time.

Likewise, we are all extremely grateful to the "patients," the pregnant women and their partners, who were willing to participate in an ethics interview.

I would like to thank Michèle Baussant, Frédéric Keck, Christophe Imbert, Anne-Marie Moulin, and again Véronique Fournier, for providing expert advice on an earlier version of this article.

Finally, I would like to thank the members of the ETHOX Center (Oxford University). They welcomed me for a two-weeks research stay in 2012 dedicated to the bibliographical preparation of the clinical ethics study.

The English editing of this paper was made possible thanks to the financial support of "La personne en medicine" Université Sorbonne Paris Cité Interdisciplinary Program.

\section{References}

Allamel-Raffin, Catherine, Dominique Merg-Essadi, Jean-Christophe Weber, Thierry Rusterholtz and Isabelle Pons. 2008. Le foetus dans l'acte d'IMG: un statut à géométrie variable. Ethique et santé, Revue des sciences sociales, 39: 126-135

Asch, Adrienne. 1999. Prenatal diagnosis and selective abortion: a challenge to practice and Policy. American Journal of Public Health, 89: 1649-1657

Bateman, Simone. 1979-1980. La grossesse accidentelle et la demande d'avortement. L'Année Sociologique, 30 : 219-241

Bateman, Simone. 1982. Les récidivistes. Revue Française de Sociologie, 23/3: 473-485

Bateman, Simone. 1982. Corps fécondable, corps réfractaire ?. Dialogue, 76: 90-95

Bateman, Simone. 1994. Les passeurs de gamètes, Nancy: Presses Universitaires de Nancy

Bateman, Simone, Jean Gayon, Sylvie Allouche, Jérôme Goffette, and Marzano Michela. 2015. Inquiring into Human Enhancement - Interdisciplinary and International Perspectives. Pelgrave McMillan

Boltanski Luc. 1990. L'amour et la justice comme compétence. Trois essais de sociologie de l'action. Paris : Métailié, 
Boltanski Luc. 2004. La condition fœtale. Une sociologie de l'engendrement et de l'avortement. Paris : Gallimard

Boltanski, Luc and Laurent Thévenot. 1991. De la justification. Les économies de la grandeur. Paris : Gallimard Dekeuwer, Catherine and Simone Bateman. 2011. Que dois-je transmettre à mes enfants ? Gravité des maladies héréditaires et choix procréatifs. In Éthique et Famille, tome 2, ed. Edwige Rude-Antoine et Marc Pievic, 143163. Paris : L'Harmattan

Dekeuwer, Catherine and Simone Bateman. 2013. Much more than a gene: Hereditary Breast and Ovarian Cancer, Reproductive Choices, and Family Life. Medicine, Health Care and Philosophy, 16/2: 231-244. DOI: $10.1007 / \mathrm{s} 11019-011-9361-9$

Dommergues, Marc, Laurent Mandelbrot, Dominique Mahieu-Caputo, Noel Boudjema, Isabelle Durand-Zaleski, et al. 2010. Termination of pregnancy following prenatal diagnosis in France: how severe are the foetal anomalies?. Prenatal Diagnosis, 30(6): 531-539

Dusart, Agnès and Dominique Thouvenin. 1995. La détection des anomalies fœtales: analyse sociologique et juridique, Paris: Les Publications du C.T.N.E.R.H.I.

Fournier, Véronique. 2010. Le bazar bioéthique - quand les histoires de vie bouleversent la morale publique, Paris : Robert Laffont

Fournier, Véronique. 2015. Puisqu'il faut bien mourir - Histoires de vie, histoires de mort : itinéraires d'une réflexion. Paris : La Découverte

Gaille, Marie. 2010. La valeur de la vie. Paris : Les Belles Lettres

Gaille, Marie and Géraldine Viot. 2013. Prenatal diagnosis as a tool and a support for eugenics: myth or reality in French contemporary society?. Medicine, Health Care and Philosophy, 16/1: 83-91

Gaille, Marie. 2014. Le retour à la vie ordinaire : un enjeu épistémologique de la réflexion philosophie morale ce que nous apprend l'enquête éthique en contexte médical. Raison publique, 18: 93-107

Gavarini, Laurence. 1990. Experts et législateurs de la normalité de l'être humain : vers un eugénisme discret. In Le magasin des enfants, ed. Jacques Testart, see below

Gayon, Jean and Daniel Jacobi. 2007. L'éternel retour de l'eugénisme. Paris: PUF

Geller, G., Tambor ES, Papiernik E, 2002. Attitudes toward abortion for fetal anomaly in the second vs the third semester : a survey of Parisian Obstetricians. Prenatal diagnosis, 22: 811-817

Geertz, Clifford. 1973. The Interpretation of Cultures. New-York: Basic Books

Glaser, Barney and Anselm Strauss. 1967. The Discovery of Grounded Theories: Strategies for Qualitative Research. New-York: A. de Gruyter

Habermas, Jürgen. Religion in the Public Sphere. Eur J Philos 14(1):1-25, 2006

Hedgecoe, Adam. 2009. Geneticization: Debates and Controversies. http://www.els.net. Accessed 18th August 2015

Kleinman, Arthur. 1988. The illness narratives: suffering, healing, and the human condition. Basic Books

Kleinman, Arthur, Veena Das and Margaret Lock. 1997. Social suffering. University of California Press

Legros, Jean-Philippe. 2005. Quand la vie avant la vie est compromise : diagnostic anténatal et découverte d'une anomalie anténatale. Spirale, 4/ 36: 79-86

Le Dref, Gaëlle, Bruno Grollemund, Anne Danion-Grilliat and Jean-Christophe Weber. 2013. Towards a new procreation ethic: the exemplary instance of cleft lip and palate. Medicine, Health Care and Philosophy. 16/3 : 365-375

Lippman, Abbey. 1992. Led (astray) by Genetics Maps. Social Science and Medicine, 12/35: 1469-1476

Massé, Raymond. 2010. Les nouveaux défis pour l'anthropologie de la santé. Anthropologie \& Santé, 1. http://anthropologiesante.revues.org/116. Accessed 18th August 2015

McCoyd, J. L. 2009. What do women want? Experiences and reflections of women after prenatal diagnosis and termination for anomaly. Health Care Women Int. 30(6): 507-535

Memmi, Dominique. 2003. Faire vivre et laisser mourir. Le gouvernement contemporain de la naissance et de la mort. Paris: La Découverte

Mirless, Véronique. et al. 2000. Medical termination of pregnancy for fetal anomaly: the patient's point of view. J Gynecol Obstet Biol Reprod (Paris), 29(2): 185-191

Mirless, Véronique. et al. 2011. Women's experience of pregnancy termination for fetal anomaly: effects of socio-political evolutions in France. Prenatal Diagnosis, 31: 1021-1028

Mathieu, Séverine. 2013. L'enfant des possibles - Assistance médicale à la procréation - éthique, religion, filiation. Paris : éd. de L'atelier

Parker, Michael. 2012. Ethical Problems and Genetics Practice. Cambridge

Rapp, Rayna. 2000. Testing Women, Testing the Fetus: The Social Impact of Amniocentesis in America (The Anthropology of Everydaylife). Routledge

Rose, Nicholas. 2007. The Politics of Life itself - Biomedicine, Power, and Subjectivity in the Twenty-First Century. Princeton University Press

Roussel, François. 1996. L’eugénisme - analyse terminée, analyse interminable ». Esprit, 222/6: 26-54 
Savulescu, Julian and Nick Bostrom. 2009. Human Enhancement. Oxford University Press

Schütz, Alfred. 2010 (2007). Essais sur le monde ordinaire. Paris: Le Félin Poche

Schmitz, Dagmar. 2013. A new era in prenatal testing: are we prepared?. Medicine, Health Care and Philosophy, $16 / 3: 357-364$

Schwennesen, Nete, Nele Svendsen, Mette Koch. 2010. Beyond informed choice: prenatal risk assessment, decision-making and trust. Clinical Ethics, $5: 207-216$

Singer, Peter and Helga Kuhse. 1985. Should the baby live? The problem of handicaped infants. Oxford University Press

Singer, Peter and Helga Kuhse. 2002. Unsanctifying human life: essays on ethics. Londres: Blackwell

Testart, Jacques. 2014. Faire des enfants demain : révolutions dans la procréation. Paris: Le Seuil

Ed. Testart, Jacques. 1990, Le Magasin des enfants. Paris: F. Bourin

Testart, Jacques. 1984. De l'éprouvette au bébé spectacle. Paris: PUF

Vassy, Carine. 2005. How prenatal diagnosis became acceptable in France. TRENDS in Biotechnology, 23/5: 246-249

Vassy, Carine. 2011. De l'innovation biomédicale à la pratique de masse : le dépistage prénatal de la trisomie 21 en Angleterre et en France. Sciences sociales et santé, 3/29: 5-32

Vassy, Carine et Béatrice Champenois-Rousseau. 2012. Les échographistes face au dépistage prénatal de la trisomie 21. Le difficile arbitrage entre excellence professionnelle et éthique du consentement. Sciences sociales et santé, 4/30: 39-63

Vassy, Carine et Béatrice Champenois-Rousseau. 2014. L'annonce prénatale d'un risque de handicap. Perspective sociologique. Contraste, 2/40: 133-144 (Vassy 2014a)

Vassy, Carine, Sophia Rosman S and Bénédicte Rousseau. 2014. From policy making to service use. Down's syndrome antenatal screening in England, France and the Netherlands. Social Sciences \& Medicine, 106 : 67-74 (Vassy 2014b)

Weber, Jean-Christophe, Catherine Allamel-Raffin, Thierry Rusterholz, Isabelle Pons and Isabelle Gobatto. 2008. Les soignants et la décision d'interruption de grossesse pour motif médical : entre indications cliniques et embarras éthiques. Sciences sociales et santé, 26/1 : 93-120

Weber, Max. 1995 (1956 4 ${ }^{\text {th }}$ Posthumous ed.). Economie et société, 1, les catégories de la sociologie. Paris : Plon/Pocket

Williams, Clare, Priscilla Alderson and Bobbie Farsides, Bobbie. 2002. Too many choices? Hospital and community staff reflect on the future of prenatal screening. Social Sciences and Medicine, 55/ 5: 743-753

Williams, Clare, P. Alderson and B. Farsides. 2002. Is nondirectiveness possible within the context of antenatal screening and testing?. Social Sciences and Medicine, 54/ 3: 339-347

Williams, Clare and Jane Sandall, Gillian Lewando-Hundt, Bob Heyman, Kevin Spencer and Rachel Grellier. 2005. Women as moral pioneers? Experiences of first trimester antenatal screening. Social sciences and Medicine, 61/ 9: 1983-1992 